Archives of Agriculture and Environmental Science

\title{
Effects of integrated weed management practices on the performance of boro rice cultivars
}

\author{
Sadia Tasmin, Md. Abdus Salam* (D) and Md. Delwar Hossain
}

Department of Agronomy, Bangladesh Agricultural University, Mymensingh-2202, BANGLADESH

*Corresponding author's E-mail: salamma71@yahoo.com

\section{ARTICLE HISTORY}

Received: 24 August 2019

Revised received: 04 September 2019

Accepted: 06 September 2019

\section{Keywords}

Boro rice

Herbicide

Integrated weed management

Rice yield

Weed suppression

\begin{abstract}
An experiment was conducted during the period from November 2016 through May 2017 to evaluate the effect of integrated weed management practices on weed suppression and on the performance of boro rice cultivars. The experiment consisted of two cultivars viz., BRRI dhan 28 and BRRI dhan 29 along with eight different weed management practices. Cultivar did not exert any significant effect on weed density and dry weight. Integrated weed management practices exerted significant effect on weed density and dry weight. The highest weed dry weight was observed in no weeding treatment and lowest one was recorded in application of pre-emergence herbicide followed by one hand weeding at 35 DAT. BRRI dhan $28 \times$ no weeding treatment produced the highest weed dry weight and BRRI dhan $28 \times$ application of preemergence herbicide followed by one HW produced the lowest weed dry weight at different DATs. BRRI dhan28 produced higher grain and straw yields than BRRI dhan29. The highest grain yield was obtained from application of pre-emergence herbicide followed by one hand weeding at 35 DAT. BRRI dhan $28 \times$ application of pre-emergence herbicide followed by one $\mathrm{HW}$ at 35 DAT produced the highest grain yield and the lowest grain yield was resulted from BRRI dhan $28 \times$ no weeding treatment. From the study it may be concluded that BRRI dhan28 $x$ application of pre-emergence herbicide followed by one HW at 35 DAT may be recommended for controlling weeds effectively and for getting the highest grain yield in boro rice.
\end{abstract}

(C)2019 Agriculture and Environmental Science Academy

Citation of this article: Tasmin, S., Salam, M.A. and Hossain, M.D. (2019). Effects of integrated weed management practices on the performance of boro rice cultivars. Archives of Agriculture and Environmental Science, 4(3): 273-280, https://dx.doi.org/10.26832/24566632.2019.040303

\section{INTRODUCTION}

About $71.06 \%$ of cropped area of Bangladesh is used for rice production, with annual production of 34.71 million tons from 11.62 million hectares of land (BBS, 2018). Among the three rice seasons boro rice occupies around 4.86 million hectares of land which is around 41.82 percent of the total rice cultivation area (BBS, 2018). The yield of boro rice in Bangladesh is increasing than in other rice growing countries of the world (FAO, 2004). But the prevailing climatic and edaphic conditions are favorable for luxuriant growth of numerous species of weeds which offer a keen competition with rice crop. In Bangladesh, weed infestation reduces the grain yield by $70-80 \%$ in aus rice (early summer), $30-40 \%$ for transplanted aman (autumn) rice and 22-
$36 \%$ for modern boro (winter) rice (Mamun, 1990; BRRI, 2008). This loss is, therefore, a serious threat for the food deficit country like Bangladesh. So, proper weed management is essential for rice production in Bangladesh.

Rice cultivars play an important role in crop-weed competition because of their diverse morphological traits, canopy structure and relative growth rate. Usually traditional tall cultivars of rice exert effective smothering effect on weeds (Prasad, 2011) and short stature cultivars face more weed infestation than taller one (Sarker, 1979). Further, it has been observed that early maturing rice cultivars and hybrid rice also have a suppressing effect on weeds due to improved vigour and having the tendency of early canopy cover (Mahajan and Chauhan, 2011).

Weeds are the most destructive crop pest. There is no doubt 
that maximum benefit from costly inputs like fertilizers and pesticides in rice can be fully derived when the crop is kept free from weed infestation. Different options are available for weed management in rice. Hand weeding is the most popular weed control method in Bangladesh. But weed control is often imperfect or delayed due to unavailability of labour during the peak period. Chemical control, on the contrary, is the most effective, economic and practical way of weed management (Hussain et al., 2008). Many researchers opined that herbicide might be considered viable alternative/ supplement to hand weeding (Mahajan et al., 2009; Chauhan and Johnson, 2011; Anwar et al., 2012a; Juraimi et al., 2013). But intensive use of herbicides may result in development of resistant weed biotypes (Rahman et al., 2010) and public health hazard (Phuong et al., 2005). The other option left is cultural weed control through adoption of different agronomic practices including tillage (Rao et al., 2007), competitive cultivar (Zhao et al., 2006; Anwar et al., 2010), seeding density (Anwar et al., 2011), water management (Rao et al., 2007), seed invigoration (Anwar et al., 2012b), stale seedbed and so on.

A single weed control approach may not be able to keep weeds below the threshold level of economic damage which demands adoption of diverse technology for weed management. Therefore, all the methods that are ecologically and economically justifiable should be integrated in a comprehensive way-known as integrated weed management (IWM). A substantial impact of IWM on rice farming has been documented by many researchers (Azmi and Baki, 2002; Sunil et al., 2010), who concluded that integration of different agronomic practices in combination with limited herbicide use managed weeds efficiently and ensured high yield. Therefore, it is necessary to use competitive rice cultivars and integration of different methods of weed management for effective weed control and obtaining higher yield. In view of the above facts this piece of work was carried out to observe the effect of rice cultivar on weed suppression, to find out the effect of different weed management techniques on the weed suppression and yield of boro rice, to assess the effect of interaction between cultivar and integrated weed management practices on weed suppression and the yield performance of boro rice.

\section{MATERIALS AND METHODS}

\section{Description of the experimental site}

Two boro rice cultivars BRRI dhan28 and BRRI dhan29 were used as experimental materials. The experiment was carried out at the Agronomy Field Laboratory of Bangladesh Agricultural University, Mymensingh during the period from November 2016 through May 2017 to study the effect of integrated weed management practices on the performance of Boro rice. The experimental area is characterized by non-calcareous dark grey floodplain soil belonging to the Sonatola soil series under the old Brahmaputra Floodplain Agro-ecological zone 9. The soil of the experimental field was more or less neutral with $\mathrm{pH}$ value 6.8, low in organic matter content and fertility status is also low. The land type was medium high with silt loam in texture. The climate of the locality is tropical in nature and is characterized by high temperature and heavy rainfall during kharif season (April to September).

\section{Experimental treatment}

The experimental treatments were as follows: Factor A: Variety (2), BRRI dhan28 $\left(\mathrm{V}_{1}\right)$, BRRI dhan29 $\left(\mathrm{V}_{2}\right)$, Factor B: Integrated weed management practices (8), No weeding $\left(\mathrm{W}_{0}\right)$, Application of pre-emergence herbicide Pretilachlor @ $2 \mathrm{~L} \mathrm{ha}^{-1}\left(\mathrm{~W}_{1}\right)$, Application of early post-emergence herbicide Pediplus (Acetachlor + Bensulfuron methyl $\left(W_{2}\right)$, Application of pre-emergence herbicide followed by early post-emergence herbicide $\left(W_{3}\right)$, Application of pre-emergence herbicide followed by one hand weeding at 35 DAT $\left(\mathrm{W}_{4}\right)$, Application of early post-emergence herbicide followed by one hand weeding at 35 DAT $\left(W_{5}\right)$, Stale seedbed $\left(W_{6}\right)$, Stale seedbed followed by application of early post emergence herbicide $\left(W_{7}\right)$. The experiment was laid out in a randomized complete block design with three replications. There were 16 treatment combinations. Total number of unit plots was 48 .

\section{Agronomic management}

Seeds of rice variety BRRI dhan28 and BRRI dhan29 were collected from the Agronomy Field Laboratory, Bangladesh Agricultural University, Mymensingh. The sprouted seeds were sown in the nursery bed on 18 November 2016. The experimental plots were fertilized with urea, triple superphosphate, muriate of potash, gypsum and zinc sulphate @ 300-100-150110-10 kg ha ${ }^{-1}$, respectively (BRRI, 2018). The entire amounts of triple superphosphate, gypsum, zinc sulphate and two thirds of muriate of potash were applied at the time of final land preparation. Urea was applied in three installments at 15, 35 and 60 days after transplanting. Rest one third muriate of potash was applied with third dose of urea. Seedlings were transplanted in the well prepared puddle field on 28 December 2016 at the rate of two seedlings hill ${ }^{-1}$, maintained row and hill distance of $25 \mathrm{~cm}$ and $15 \mathrm{~cm}$ in conventional method. In case of stale seedbed, seedlings were transplanted in the plot on 7 January 2017. The crop of each plot was harvested from $1 \mathrm{~m}^{2}$ of the central area with sickle at full maturity. Just before harvesting five hills excluding the border plants and the harvest area of each plot were selected at random and uprooted for collecting data on yield components. BRRI dhan28 was harvested on 29 April and BRRI dhan29 on 7 May 2017. Then the harvested crops of each plot was bundled separately, properly tagged and brought to threshing floor. The crops were then threshed and dry weight of grain and straw were recorded.

\section{Data collection}

The data of weed parameters were collected at 25 DAT, 50 DAT and 75 DAT of rice plants. Weed parameters such as weed density (no. $\mathrm{m}^{-2}$ ) and weed dry weight $\left(\mathrm{g} \mathrm{m}^{-2}\right)$ were collected. Crop characters such as plant height $(\mathrm{cm})$, number of total tillers hill $^{-1}$, number of effective tillers hill ${ }^{-1}$, tillers hill ${ }^{-1}$, panicle length, number of grains panicle $e^{-1}$, number of sterile spikelets panicle ${ }^{-1}$, $1000^{-}$grain weight, grain yield, straw yield and harvest index were recorded. 


\section{Statistical analysis}

All the recorded data were compiled and tabulated for statistical analysis. The collected data were analyzed following the analysis of variance (ANOVA) technique and mean differences were adjusted by Duncan's Multiple Range Test (DMRT) (Gomez and Gomez, 1984) using a computer operated program namely, MSTAT-C.

\section{RESULTS AND DISCUSSION}

Effect of cultivar on weed density and weed dry weight Weed density at 25, 50 and 75 DATs was not significantly influenced by variety. Numerically the higher weed density was found in BRRI dhan28, showing the higher values of $55.96 \mathrm{~m}^{-2}$, and $70.33 \mathrm{~m}^{-2}$ at 25 and 50 DATs, respectively and the lower weed density was obtained in BRRI dhan29, exhibit the lower values of $54.83 \mathrm{~m}^{-2}$, and $69.67 \mathrm{~m}^{-2}$ at 25 and 50 DATs, respectively. At 75 DAT, the higher weed density $\left(53.17 \mathrm{~m}^{-2}\right)$ was found in BRRI dhan29 and the lower number of weed density $\left(51.46 \mathrm{~m}^{-2}\right)$ was obtained in BRRI dhan28 (Table 1). Similar research findings were also reported by Islam et al. (2017) who reported that weed density at 40 and 60 DATs was not significantly affected by varieties. Weed dry weight at 25,50 and 75 DATs was not significantly influenced by cultivar. At 25, 50 and 75 DAT numerically the higher weed dry weight of 2.51, 10.06 and $17.08 \mathrm{~g} \mathrm{~m}^{-2}$, respectively was found in BRRI dhan29 and the lower weed dry weight of 2.38, 9.44 and $15.38 \mathrm{~g} \mathrm{~m}^{-2}$, respectively was found in BRRI dhan28 cultivar (Table 1). This finding corroborates the findings of Islam et al. (2017) who reported that total weed dry weight was not significantly affected by the cultivars at 20, 40 and 60 DATs.

Effect of weed management practices on weed density and dry weight

Weed density $\left(\mathrm{m}^{-2}\right)$ was significantly influenced by weed management at 25, 50 and 75 DATs. At 25 DAT, the highest weed density $\left(109.80 \mathrm{~m}^{-2}\right.$ ) was found in $\mathrm{W}_{0}$ (no weeding) and the lowest one $\left(13.33 \mathrm{~m}^{-2}\right.$ ) was found in $\mathrm{W}_{3}$ (application of pre-emergence herbicide followed by early post-emergence herbicide) treatment which was statistically identical to $W_{1}$ (application of pre-emergence herbicide) and $\mathrm{W}_{4}$ (application of pre-emergence herbicide followed by one hand weeding at 35
DAT). At 50 DAT, the highest weed density $\left(166.00 \mathrm{~m}^{-2}\right)$ was found in $W_{0}$ (no weeding) treatment which was statistically identical to $W_{6}$ (stale seedbed) and the lowest one $\left(16.00 \mathrm{~m}^{-2}\right)$ was found in $W_{3}$ (application of pre-emergence herbicide followed by early post-emergence herbicide) treatment (Table 2). At 75 DAT, the highest weed density $\left(115.50 \mathrm{~m}^{-2}\right)$ was found in $W_{0}$ (No weeding) and the lowest one $\left(14.00 \mathrm{~m}^{-2}\right)$ was found in $\mathrm{W}_{3}$ (application of pre-emergence herbicide followed by early post-emergence herbicide) (Table 2). Mou et al. (2017) and Islam et al. (2017) reported in their study that no weeding treatment recorded the higher weed population than different weed control treatments. Weed management practices exerted significant effect on weed dry weight at 25,50 and 75 DATs. At 25 DAT, the highest weed dry weight $\left(3.35 \mathrm{~g} \mathrm{~m}^{-2}\right)$ was found in $\mathrm{W}_{0}$ (No weeding) and the lowest one $\left(1.91 \mathrm{~g} \mathrm{~m}^{-2}\right)$ was found in $\mathrm{W}_{4}$ (application of pre-emergence herbicide followed by one hand weeding at 35 DAT) treatment which was significantly different from other treatments. On the other hand, $W_{1}$ (application of pre-emergence herbicide), $\mathrm{W}_{3}$ (application of pre -emergence herbicide followed by early post-emergence herbicide) and $W_{7}$ (stale seedbed followed by application of early post-emergence herbicide) treatments were statistically identical. At 50 DAT, the highest weed dry weight $\left(24.15 \mathrm{~g} \mathrm{~m}^{-2}\right)$ was found in $W_{0}$ (no weeding) and the lowest one $\left(2.29 \mathrm{~g} \mathrm{~m}^{-2}\right.$ ) was found in $W_{4}$ (application of pre-emergence herbicide followed by one hand weeding at 35 DAT) treatment. Treatments $W_{3}$ (application of pre-emergence herbicide followed by early post-emergence herbicide), $W_{4}$ (application of preemergence herbicide followed by one hand weeding at 35 DAT) and $W_{5}$ (application of early post-emergence herbicide followed by one hand weeding at 35 DAT) were statistically identical. At 75 DAT, the highest weed dry weight $\left(36.89 \mathrm{~g} \mathrm{~m}^{-2}\right)$ was found in $\mathrm{W}_{0}$ (no weeding) which was statistically identical to $\mathrm{W}_{6}$ (stale seedbed) and the lowest weed dry weight $\left(5.50 \mathrm{~g} \mathrm{~m}^{-2}\right)$ was found in $\mathrm{W}_{4}$ (application of pre-emergence herbicides followed by one hand weeding at 35 DAT) treatment which was statistically identical to $W_{3}$ (application of pre-emergence herbicide followed by early post-emergence herbicide) treatment (Table 2). Mou et al. (2017) and Islam et al. (2017) reported highest weed dry weight in no weeding treatment and the lower weed dry weight was observed in different weed management practices.

Table 1. Effect of cultivar on weed population and weed dry matter at different days after transplanting.

\begin{tabular}{lcccccc}
\hline \multirow{2}{*}{ Cultivar } & \multicolumn{3}{c}{ Weed density $\left(\right.$ no. $\left.\mathbf{~}^{-2}\right)$} & \multicolumn{3}{c}{ Weed dry matter $\left(\mathrm{g} \mathrm{m}^{-2}\right)$} \\
\cline { 2 - 7 } & 25DAT & 50DAT & 75DAT & 25DAT & 50DAT & 75DAT \\
\hline BRRI dhan28 & 55.96 & 70.33 & 51.46 & 2.38 & 9.45 & 15.38 \\
BRRI dhan29 & 54.83 & 69.67 & 53.17 & 2.51 & 10.06 & 17.08 \\
Level of sig. & NS & NS & NS & NS & NS & 25.49 \\
CV (\%) & 19.65 & 25.94 & 27.49 & 2.58 & 19.26 \\
\hline
\end{tabular}

NS = Not Significant. 
Table 2. Effect of methods of weed management on weed population and weed dry weight at different days after transplanting.

\begin{tabular}{|c|c|c|c|c|c|c|}
\hline \multirow{2}{*}{$\begin{array}{l}\text { Methods of weed } \\
\text { management }\end{array}$} & \multicolumn{3}{|c|}{ Weed density (no. $\mathrm{m}^{-2}$ ) } & \multicolumn{3}{|c|}{ Weed dry matter $\left(\mathrm{g} \mathrm{m}^{-2}\right)$} \\
\hline & 25DAT & 50DAT & 75DAT & 25DAT & 50DAT & 75DAT \\
\hline $\mathrm{W}_{0}$ & 109.80a* & $166.00 \mathrm{a}$ & $115.50 \mathrm{a}$ & $3.357 a$ & $24.15 a$ & $36.89 a$ \\
\hline$W_{1}$ & $17.33 e$ & $41.33 b c$ & $34.67 d$ & $2.26 \mathrm{~cd}$ & $5.27 \mathrm{de}$ & $9.10 \mathrm{~cd}$ \\
\hline$W_{2}$ & $62.00 d$ & $64.00 \mathrm{~b}$ & $37.33 d$ & $2.31 \mathrm{bcd}$ & $7.49 d$ & $12.40 c$ \\
\hline$W_{3}$ & $13.33 e$ & $16.00 c$ & $14.00 \mathrm{e}$ & $1.95 \mathrm{~cd}$ & $3.21 \mathrm{e}$ & $7.65 d$ \\
\hline$W_{4}$ & $14.00 \mathrm{e}$ & $34.00 b c$ & $22.17 \mathrm{de}$ & $1.91 d$ & $2.29 e$ & $5.500 d$ \\
\hline$W_{5}$ & $79.33 c$ & $40.00 b c$ & $36.00 d$ & $2.67 a b c$ & $2.42 \mathrm{e}$ & $8.750 \mathrm{~cd}$ \\
\hline$W_{6}$ & $96.67 \mathrm{~b}$ & $142.0 \mathrm{a}$ & $97.17 \mathrm{~b}$ & 2.97ab & $18.07 \mathrm{~b}$ & $33.25 a$ \\
\hline$W_{7}$ & $50.67 d$ & $56.67 \mathrm{~b}$ & $61.67 c$ & $2.18 \mathrm{~cd}$ & $15.13 c$ & $16.30 \mathrm{~b}$ \\
\hline Level of sig. & 0.01 & 0.01 & 0.01 & 0.01 & 0.01 & 0.01 \\
\hline CV (\%) & 19.65 & 25.94 & 27.49 & 22.58 & 25.49 & 19.26 \\
\hline
\end{tabular}

${ }^{*}$ In a column, figures with the same letter (s) or without letter do not differ significantly whereas figures with dissimilar letter differ significantly (as per DMRT).

Table 3. Interaction effect of cultivar and methods of weed management on weed population and weed dry weight.

\begin{tabular}{|c|c|c|c|c|c|c|}
\hline \multirow{2}{*}{$\begin{array}{l}\text { Cultivar } \times \text { Method } \\
\text { of weed management }\end{array}$} & \multicolumn{3}{|c|}{ Weed population (no. $\mathrm{m}^{-2}$ ) } & \multicolumn{3}{|c|}{ Weed dry matter $\left(\mathrm{g} \mathrm{m}^{-2}\right)$} \\
\hline & 25DAT & 50DAT & 75DAT & 25DAT & 50DAT & 75DAT \\
\hline $\mathrm{V}_{1} \mathrm{~W}_{0}$ & 109.0 & 162.7 & 113.7 & $3.707 a^{*}$ & 23.09 & 37.53 \\
\hline $\mathrm{V}_{1} \mathrm{~W}_{1}$ & 20.00 & 40.00 & 25.33 & $2.547 b c$ & 5.147 & 8.59 \\
\hline $\mathrm{V}_{1} \mathrm{~W}_{2}$ & 61.33 & 65.33 & 26.67 & $1.947 \mathrm{~cd}$ & 8.733 & 9.99 \\
\hline $\mathrm{V}_{1} \mathrm{~W}_{3}$ & 17.33 & 22.67 & 12.00 & $1.240 \mathrm{~d}$ & 2.667 & 4.04 \\
\hline $\mathrm{V}_{1} \mathrm{~W}_{4}$ & 17.33 & 41.33 & 24.33 & $1.200 \mathrm{~d}$ & 2.293 & 5.73 \\
\hline$V_{1} W_{5}$ & 70.67 & 41.33 & 36.00 & $2.853 a b c$ & 2.173 & 8.33 \\
\hline$v_{1} W_{6}$ & 96.00 & 128.0 & 109.0 & $3.180 a b$ & 16.57 & 34.40 \\
\hline$v_{1} W_{7}$ & 56.00 & 61.33 & 64.67 & $2.427 b c$ & 14.89 & 14.39 \\
\hline$v_{2} W_{0}$ & 110.7 & 169.3 & 117.3 & $2.987 \mathrm{abc}$ & 25.20 & 36.25 \\
\hline $\mathrm{V}_{2} \mathrm{~W}_{1}$ & 14.67 & 42.67 & 44.00 & $1.973 \mathrm{~cd}$ & 5.400 & 9.62 \\
\hline$V_{2} W_{2}$ & 62.67 & 62.67 & 48.00 & $2.680 a b c$ & 6.240 & 14.80 \\
\hline $\mathrm{V}_{2} \mathrm{~W}_{3}$ & 9.333 & 9.333 & 16.00 & $2.667 \mathrm{abc}$ & 3.747 & 11.25 \\
\hline $\mathrm{V}_{2} \mathrm{~W}_{4}$ & 10.67 & 26.67 & 20.00 & $2.627 \mathrm{bc}$ & 2.293 & 5.27 \\
\hline$V_{2} W_{5}$ & 88.00 & 38.67 & 36.00 & $2.480 \mathrm{bc}$ & 2.667 & 9.17 \\
\hline$v_{2} W_{6}$ & 97.33 & 156.0 & 85.33 & $2.760 a b c$ & 19.57 & 32.11 \\
\hline$v_{2} W_{7}$ & 45.33 & 52.00 & 58.67 & $1.927 \mathrm{~cd}$ & 15.36 & 18.20 \\
\hline Level of sig. & NS & NS & NS & 0.01 & NS & NS \\
\hline $\mathrm{CV}(\%)$ & 19.65 & 35.94 & 27.49 & 22.58 & 25.49 & 19.26 \\
\hline
\end{tabular}

*In a column, figures with the same letter ( $\mathrm{s}$ ) or without letter do not differ significantly as per DMRT; NS = Not Significant; $\mathrm{V}_{1}=\mathrm{BRRI}$ dhan28, $\mathrm{V}_{2}=$ BRRI dhan29; $W_{0}=$ No weeding, $W_{1}=$ Application of pre-emergence herbicide, $W_{2}=$ Application of early post- emergence herbicide, $W_{3}=A p p l i c a t i o n$ of pre-emergence herbicide followed by application of early post- emergence herbicide, $W_{4}=$ Application of pre-emergence herbicide followed by one hand weeding at $35 \mathrm{DAT}, \mathrm{W}_{5}=$ Application of early post-emergence herbicide followed by one hand weeding at $35 \mathrm{DAT}, \mathrm{W}_{6}=\mathrm{Stale}$ seedbed, $\mathrm{W}_{7}=$ Stale seedbed followed by application of early post-emergence herbicide.

Interaction effect of cultivar and weed management practices on total weed population and weed dry matter

No significant variation was found in weed density due to interaction of cultivar and weed management practices at 25 , 50 and 75 DATs. Similar research finding was also reported by Parvez et al. (2013). At 25 DAT, numerically the highest weed density $\left(110.7 \mathrm{~m}^{-2}\right.$ ) was found in $\mathrm{V}_{2} \mathrm{~W}_{0}$ (BRRI dhan $29 \times$ no weeding) and the lowest one $\left(9.33 \mathrm{~m}^{-2}\right)$ was found in $\mathrm{V}_{2} \mathrm{~W}_{3}$ (BRRI dhan $29 \times$ application of pre-emergence herbicide followed by early post-emergence herbicide). At 50 DAT, numerically the highest weed population $\left(169.30 \mathrm{~m}^{-2}\right)$ was found in $\mathrm{V}_{2} \mathrm{~W}_{0}$ (BRRI dhan29 $\times$ no weeding) and the lowest one $\left(9.33 \mathrm{~m}^{-2}\right)$ was found in $\mathrm{V}_{2} \mathrm{~W}_{3}$ (BRRI dhan $29 \times$ application of pre-emergence herbicide followed by early post-emergence herbicide). At 75 DAT, numerically the highest weed population $\left(117.3 \mathrm{~m}^{-2}\right)$ was found in $\mathrm{V}_{2} \mathrm{~W}_{0}$ (BRRI dhan $29 \times$ no weeding) and the lowest one (12.00 $\mathrm{m}^{-2}$ ) was found in $\mathrm{V}_{1} \mathrm{~W}_{3}$ (BRRI dhan28 $\times$ application of pre-emergence herbicide followed by early post-emergence herbicide) (Table 3). Significant variation was found in weed dry weight due to interaction of cultivar and weed management practices at 25 DAT. The highest weed dry matter $\left(3.71 \mathrm{~g} \mathrm{~m}^{-2}\right)$ was found in $\mathrm{V}_{1} \mathrm{~W}_{0}$ (BRRI dhan $28 \times$ no weeding) treatment, while the lowest weed dry matter $\left(1.20 \mathrm{~g} \mathrm{~m}^{-2}\right)$ was found in $\mathrm{V}_{1} \mathrm{~W}_{4}$ (BRRI dhan28 $\times$ application of pre-emergence herbicide followed by one hand weeding at 35 DAT) treatment which was statistically identical to $\mathrm{V}_{1} \mathrm{~W}_{3}$ (BRRI dhan $28 \times$ application of pre-emergence herbicide followed by early post-emergence herbicide). There was no significant variation found in weed dry weight due to interaction between cultivar and weed management practices at 50 and 75 DAT (Table 3). This finding corroborates the findings of Parvez et al. (2013). 
Effect of cultivar on the yield and yield contributing characters of boro rice

The plant height was not varied significantly by the cultivars. Numerically the taller plant $(80.33 \mathrm{~cm})$ was found in BRRI dhan29 than in BRRI dhan28 $(80.13 \mathrm{~cm})$ (Table 4). Total and effective tillers hill $^{-1}$ were not significantly influenced by cultivars. Numerically the higher number of tillers hill ${ }^{-1}$ (10.96) and effective tillers hill ${ }^{-1}$ (9.12) were observed in BRRI dhan28 than BRRI dhan29 (Table 4). Panicle length and grains panicle ${ }^{-1}$ were not significantly affected by different cultivars. However, numerically the longer panicle $(21.06 \mathrm{~cm})$ and higher number of grains panicle $^{-1}$ (85.75) were recorded in cultivar BRRI dhan28 and shorter panicle $(21.00 \mathrm{~cm})$ and lower number of grains pani$\mathrm{cle}^{-1}$ (85.46) were recorded in BRRI dhan29 (Table 4). Number of sterile spikelets panicle ${ }^{-1}$ was not significantly affected by different cultivars. Numerically the higher number of sterile spikelets panicle $^{-1}$ (17.92) was observed in BRRI dhan29 and the lower one (17.62) was found in BRRI dhan28 (Table 4). Numerically the heavier thousand grain weight (21.32 g) was recorded in BRRI dhan28 and lower one (21.16 g) was recorded in BRRI dhan29 (Table 4). The cultivars studied differed significantly in respect of grain yield. Higher grain yield (5.17 $\left.\mathrm{t} \mathrm{ha} \mathrm{a}^{-1}\right)$ was obtained in BRRI dhan28 and the lower grain yield (4.88 $\mathrm{t} \mathrm{ha}^{-1}$ ) was obtained in BRRI dhan29 cultivar. Variation in grain yield of rice due to cultivars was also reportd by Parvez et al. (2013), Islam et al. (2017) and Mou et al. (2017). Straw yield was not significantly influenced by cultivar. Numerically higher straw yield (6.43 $\mathrm{t} \mathrm{ha}^{-1}$ ) was found in BRRI dhan28 and lower one (6.37 $\mathrm{t} \mathrm{ha}^{-1}$ ) was found in BRRI dhan29. Harvest index was significantly influenced by cultivar. Higher harvest index (43.61\%) was obtained in BRRI dhan28 and lower harvest index (42.59\%) was obtained in BRRI dhan29 (Table 4).

Effect of weed management practices on yield and yield contributing characters of boro rice

Plant height was not significantly affected by different weed management practices. Numerically the tallest plant $\left(81.97 \mathrm{~cm}\right.$ ) was found in $\mathrm{W}_{3}$ (application of pre-emergence herbicide followed by early post-emergence herbicide) treatment. The shortest plant $(78.73 \mathrm{~cm})$ was found in $W_{2}$ (application of early post-emergence herbicide) treatment (Table 5).

Table 4. Effect of cultivars on yield and yield contributing characters of boro rice.

\begin{tabular}{|c|c|c|c|c|c|c|c|c|c|c|}
\hline Cultivar & $\begin{array}{l}\text { Plant } \\
\text { height } \\
(\mathrm{cm})\end{array}$ & $\begin{array}{c}\text { Total tillers } \\
\text { hill }^{-1} \\
\text { (no.) }\end{array}$ & $\begin{array}{l}\text { Effective } \\
\text { tillers } \\
\text { hill }^{-1} \\
\text { (no.) }\end{array}$ & $\begin{array}{l}\text { Length of } \\
\text { panicle } \\
\text { (cm) }\end{array}$ & $\begin{array}{l}\text { Grain } \\
\text { panicle } \\
\text { (no.) }\end{array}$ & $\begin{array}{l}\text { Sterile } \\
\text { spikelets } \\
\text { panicle }{ }^{-1} \\
\text { (no.) }\end{array}$ & $\begin{array}{c}\text { 1000- grain } \\
\text { weight (g) }\end{array}$ & $\begin{array}{l}\text { Grain } \\
\text { yield } \\
\left(\mathrm{t} \mathrm{ha}^{-1}\right)\end{array}$ & $\begin{array}{c}\text { Straw } \\
\text { yield } \\
\left(\mathrm{t} \mathrm{ha}^{-1}\right)\end{array}$ & $\begin{array}{c}\text { Harvest } \\
\text { index } \\
(\%)\end{array}$ \\
\hline BRRI dhan28 & 80.13 & 10.96 & 9.12 & 21.06 & 85.46 & 17.67 & 21.32 & 5.171a* & 6.43 & $43.61 a$ \\
\hline BRRI dhan29 & 80.33 & 10.33 & 8.70 & 21.00 & 85.75 & 17.92 & 21.16 & $4.875 b$ & 6.37 & $42.59 b$ \\
\hline Level of sig. & NS & NS & NS & NS & NS & NS & NS & 0.01 & NS & 0.01 \\
\hline CV (\%) & 2.95 & 10.49 & 12.68 & 1.82 & 3.48 & 13.79 & 6.79 & 2.51 & 1.37 & 1.85 \\
\hline
\end{tabular}

*In a column, figures with the same letter (s) or without letter do not differ significantly whereas figures with dissimilar letter differ significantly (as per DMRT); NS = Not Significant.

Table 5. Effect of methods of weed management on yield and yield contributing characters of boro rice cultivars.

\begin{tabular}{|c|c|c|c|c|c|c|c|c|c|c|}
\hline $\begin{array}{l}\text { Weed } \\
\text { management } \\
\text { practices }\end{array}$ & $\begin{array}{l}\text { Plant } \\
\text { height } \\
(\mathrm{cm})\end{array}$ & $\begin{array}{c}\text { Total } \\
\text { tillers hill }^{-1} \\
\text { (no.) }\end{array}$ & $\begin{array}{c}\text { Effective } \\
\text { tillers hill }^{-1} \\
\text { (no.) }\end{array}$ & $\begin{array}{l}\text { Length } \\
\text { of } \\
\text { panicle } \\
\text { (cm) }\end{array}$ & $\begin{array}{l}\text { Grains } \\
\text { panicle } \\
\text { (no.) }\end{array}$ & $\begin{array}{l}\text { Sterile } \\
\text { spikelets } \\
\text { panicle }{ }^{-1} \\
\text { (no.) }\end{array}$ & $\begin{array}{l}\text { 1000- grain } \\
\text { weight } \\
\text { (g) }\end{array}$ & $\begin{array}{l}\text { Grain } \\
\text { yield } \\
\left(\mathrm{t} \mathrm{ha}^{-1}\right)\end{array}$ & $\begin{array}{l}\text { Straw } \\
\text { yield } \\
\left(\mathrm{t} \mathrm{ha}^{-1}\right)\end{array}$ & $\begin{array}{c}\text { Harvest } \\
\text { index } \\
(\%)\end{array}$ \\
\hline $\mathrm{W}_{0}$ & 79.68 & $8.667 c^{*}$ & $6.833 c^{*}$ & 20.92 & $107.40 \mathrm{e}$ & $19.83 a$ & $20.73 a b c$ & $1.99 \mathrm{f}$ & $4.28 \mathrm{e}$ & $31.73 d$ \\
\hline$W_{1}$ & 80.23 & 12.83ab & $10.75 a b$ & 20.65 & $133.00 \mathrm{c}$ & 19.33ab & $21.23 a b c$ & $5.59 c$ & $6.82 \mathrm{~b}$ & $45.04 b$ \\
\hline$W_{2}$ & 78.73 & 13.00ab & 11.17ab & 21.25 & $136.90 b c$ & 19.00abc & $20.13 c$ & $5.69 c$ & $6.87 \mathrm{~b}$ & 45.27ab \\
\hline$W_{3}$ & 81.97 & $13.83 a$ & $12.32 \mathrm{a}$ & 21.18 & $138.90 \mathrm{~b}$ & $15.83 \mathrm{~cd}$ & 22.10ab & $5.87 b$ & $7.21 a$ & $44.88 b$ \\
\hline$W_{4}$ & 81.52 & $13.67 a$ & $12.27 a$ & 21.00 & 147.70a & $18.00 \mathrm{a}-\mathrm{d}$ & $22.17 a b$ & $6.19 a$ & $7.22 a$ & $46.16 a$ \\
\hline$W_{5}$ & 81.15 & $13.83 a$ & $12.08 \mathrm{a}$ & 21.30 & $140.30 \mathrm{~b}$ & 18.17a-d & $20.43 b c$ & $5.60 c$ & $6.86 \mathrm{~b}$ & $44.95 b$ \\
\hline $\mathrm{W}_{6}$ & 78.92 & $11.50 \mathrm{~b}$ & $9.733 b$ & 21.07 & $117.80 d$ & $15.67 d$ & $20.63 a b c$ & $3.99 \mathrm{e}$ & $5.42 d$ & 42.37c \\
\hline$W_{7}$ & 79.65 & $12.50 \mathrm{ab}$ & 10.87ab & 20.88 & $134.80 \mathrm{bc}$ & $16.50 \mathrm{bcd}$ & $22.47 a$ & $5.26 \mathrm{~d}$ & $6.58 c$ & $44.43 b$ \\
\hline Level of sig. & NS & 0.01 & 0.01 & NS & 0.01 & 0.01 & 0.05 & 0.01 & 0.01 & 0.01 \\
\hline CV (\%) & 2.95 & 10.49 & 12.68 & 1.82 & 3.48 & 13.79 & 6.79 & 2.51 & 1.37 & 1.85 \\
\hline
\end{tabular}

*In a column, figures with the same letter (s) or without letter do not differ significantly whereas figures with dissimilar letter differ significantly (as per DMRT), NS = Not significant; $W_{0}=$ No weeding, $W_{1}=$ Application of pre-emergence herbicide, $W_{2}=$ Application of early post- emergence herbicide, $\mathrm{W}_{3}=$ Application of pre-emergence herbicide followed by application of early post- emergence herbicide, $\mathrm{W}_{4}=$ Application of pre-emergence herbicide followed by one hand weeding at 35 DAT, $W_{5}=$ Application of early post-emergence herbicide followed by one hand weeding at $35 \mathrm{DAT}, \mathrm{W}_{6}=$ Stale seedbed, $\mathrm{W}_{7}=$ Stale seedbed followed by application of early post-emergence herbicide. 
The highest number of total tillers hill $^{-1}$ (13.83) was observed in $\mathrm{W}_{3}$ (application of pre-emergence herbicide followed by early post-emergence herbicide) treatment which was statistically identical to $W_{4}$ (application of pre-emergence herbicide followed by one hand weeding at 35 DAT) and $W_{5}$ (application of early post-emergence herbicide followed by one hand weeding at 35 DAT). The lowest number total tillers hill ${ }^{-1}$ (8.67) was observed in $W_{0}$ (No weeding) treatment. In no weeding treatment weed crop competition was higher and weed suppressed the rice plant growth ultimately tiller number was reduced (Table 5). Number of effective tillers hill $^{-1}$ was significantly influenced by different weed management practices. The highest number of effective tillers hill ${ }^{-1}$ (12.32) was observed in $W_{3}$ (application of pre-emergence herbicide followed by early post-emergence herbicide) treatment which was statistically identical to $W_{4}$ (application of pre-emergence herbicide followed by one hand weeding at 35 DAT) and $W_{5}$ (application of early postemergence herbicides followed by one hand weeding at 35 DAT). The lowest effective tillers hill-1 (6.83) was observed in $W_{0}$ (no weeding) treatment. Weeds were controlled effectively in $W_{3}, W_{4}$ and $W_{5}$ treatments. Therefore crop weed competition was lower and hence rice growth was vigorous in those treatments and highest number of effective tillers was observed in $\mathrm{W}_{3}, \mathrm{~W}_{4}$ and $\mathrm{W}_{5}$ treatments. Similar research finding was also repeated by Mou et al (2017). Panicle length was not significantly affected by weeding regime. Numerically the longest panicle $(21.30 \mathrm{~cm})$ was observed in $W_{5}$ (application of early postemergence herbicides followed by one hand weeding at 35 DAT) treatment and the shortest one $(20.65 \mathrm{~cm})$ was observed in $\mathrm{W}_{1}$ (application of pre-emergence herbicide) treatment (Table 5). Number of grains panicle ${ }^{-1}$ was significantly affected by different weeding regimes. The highest number of grains panicle ${ }^{-1}$ (147.70) was observed in $W_{4}$ (application of pre-emergence herbicides followed by one hand weeding at 35 DAT) treatment, while the lowest one (107.40) was observed in $\mathrm{W}_{0}$ (no weeding) treatment. In this study, $\mathrm{W}_{4}$ (application of pre-emergence herbicide followed by one hand weeding at 35 DAT) produced the highest number of grains panicle ${ }^{-1}$ which might be attributed due to vigorous growth of rice plant because of less competition with weed. Number of sterile spikelets panicle ${ }^{-1}$ was significantly affected by different weed management practices. The highest number of sterile spikelets panicle ${ }^{-1}$ (19.83) was observed in $\mathrm{W}_{0}$ (no weeding) treatment, while the lowest number of sterile spikelets panicle ${ }^{-1}$ (15.67) was observed in $\mathrm{W}_{6}$ (stale seedbed) treatment (Table 5). Weight of 1000 -grain was significantly affected by different weed management practices. The heaviest thousand grain weight $\left(22.47 \mathrm{~g}\right.$ ) was recorded in $\mathrm{W}_{7}$ (stale seedbed followed by application of early post-emergence herbicide) treatment, while the lowest thousand grain weight $(20.13 \mathrm{~g}$ ) was recorded in $W_{2}$ (application of early post-emergence herbicide) treatment. Treatment $W_{0}$ (no weeding), $W_{1}$ (application of preemergence herbicide) and $W_{6}$ (stale seedbed) were slightly simi$\operatorname{lar}$ (Table 5). On the other hand, treatment $\mathrm{W}_{3}$ (application of pre-emergence herbicide followed by early post-emergence herbicide) and $W_{4}$ (application of pre-emergence herbicides followed by one hand weeding at 35 DAT) were statistically similar. Grain yield was significantly influenced by different weeding regimes. The highest grain yield $\left(6.19 \mathrm{t} \mathrm{ha}^{-1}\right)$ was observed in $\mathrm{W}_{4}$ (application of pre-emergence herbicide followed by one hand weeding at 35 DAT) treatment, while the lowest grain yield (1.99 $\mathrm{t} \mathrm{ha}^{-1}$ ) was observed in $\mathrm{W}_{0}$ (no weeding) treatment. Similar research finding was alos reported by Parvez et al. (2013) who reported that application of pre-emergence herbicide followed by one hand weeding at 35 DAT produced the highest grain yield of rice. Treatments $W_{1}$ (application of pre -emergence herbicide), $W_{2}$ (application of early post-emergence herbicide) and $W_{5}$ (application of early post-emergence herbicide followed by one hand weeding at 35 DAT) were statistically similar. The increased yield was contributed in $\mathrm{W}_{4}$ (application of pre-emergence herbicides followed by one hand weeding at 35 DAT) treatment due to higher number of effective tiller hill ${ }^{-1}$, higher number of grains pancicle ${ }^{-1}$ over no weeding treatment. This might be due to the fact that in the $W_{4}$ treatment, weeds were controlled effectively and the rice field was weed free and soil was well aerated which facilitated the crop for absorption of greater amount of plant nutrients, moisture and greater reception of solar radiation for better growth. Straw yield was significantly influenced by different weeding regimes. The highest straw yield (7.22 $\mathrm{t} \mathrm{ha}^{-1}$ ) was observed in $\mathrm{W}_{4}$ (application of pre-emergence herbicides followed by one hand weeding at 35 DAT) treatment which was statistically identical with $W_{3}$ (application of pre-emergence herbicide followed by early postemergence herbicide) treatment, while the lowest straw yield (4.28 $\mathrm{t} \mathrm{ha}^{-1}$ ) was observed in $\mathrm{W}_{0}$ (no weeding) treatment). Harvest index was significantly influenced by different weed management practices. The highest harvest index (46.16\%) was observed in $\mathrm{W}_{4}$ (application of pre-emergence herbicides followed by one hand weeding at 35 DAT). The lowest harvest index (31.73\%) was observed in $\mathrm{W}_{0}$ (no weeding) treatment (Table 5).

Interaction effect of cultivar and weed management practices on yield and yield contributing characters of boro rice

The interaction effect of cultivar and weed management practices was significant for plant height. The tallest plant $(83.60 \mathrm{~cm})$ was obtained from $\mathrm{V}_{1} \mathrm{~W}_{4}$ (BRRI dhan $28 \times$ application of preemergence herbicide followed by one hand weeding at 35 DAT) treatment and the one $\left(75.60 \mathrm{~cm}\right.$ ) was found in $\mathrm{V}_{1} \mathrm{~W}_{6}$ (BRRI dhan28 $\times$ stale seedbed) treatment (Table 6). Non significant variation in total and effective tillers hill ${ }^{-1}$ due to interaction of cultivar and weed management was observed in the study. Numerically the highest number of total tillers hill ${ }^{-1}$ (14.67) and effective tillers hill ${ }^{-1}$ (13.33) were produced in $\mathrm{V}_{1} \mathrm{~W}_{3}$ (BRRI dhan28 $\times$ application of pre-emergence herbicide and $V_{1} W_{4}$ (BRRI dhan28 $\times$ application of pre-emergence herbicide followed by one hand weeding at 35 DAT) treatment, respectively, while the lowest number of total tillers hill ${ }^{-1}$ (8.33) and effective tillers hill $^{-1}$ (6.67) were produced in $\mathrm{V}_{1} \mathrm{~W}_{0}$ (BRRI dhan28 $\times$ no weeding) treatment (Table 6). Panicle length was not significantly influenced by interaction of cultivar and weed 
management practices. Apparently the longest panicle (21.47 $\mathrm{cm}$ ) was observed in $\mathrm{V}_{1} \mathrm{~W}_{5}$ (BRRI dhan $28 \times$ application of early post-emergence herbicide followed by one hand weeding at 35 DAT) treatment and the shortest one $(20.33 \mathrm{~cm})$ was found in $\mathrm{V}_{1} \mathrm{~W}_{1}$ (BRRI dhan $28 \times$ application of pre-emergence herbicide) treatment (Table 6). Number of grains panicle ${ }^{-1}$ was significantly influenced by interaction of cultivar and weed management practices. The highest number of grains panicle ${ }^{-1}$ (157.50) was produced by $\mathrm{V}_{1} \mathrm{~W}_{4}$ (BRRI dhan28 $\times$ application of preemergence herbicide followed by one hand weeding at 35 DAT) treatment, while the lowest one (106.30) was produced by $\mathrm{V}_{2} \mathrm{~W}_{0}$ (BRRI dhan $29 \times$ no weeding) treatment which was statistically identical to $\mathrm{V}_{1} \mathrm{~W}_{0}$ (BRRI dhan $28 \times$ no weeding), and $\mathrm{V}_{2} \mathrm{~W}_{6}$ (BRRI dhan29 $\times$ stale seedbed) (Table 6). There was no significant variation in number of sterile spikelets panicle ${ }^{-1}$ due to interaction of cultivar and different weeding regimes. Weight of 1000-grain was not significantly affected by interaction of cultivar and different weeding regimes. Numerically the heaviest 1000-grain weight $\left(23.20 \mathrm{~g}\right.$ ) was obtained in $\mathrm{V}_{1} \mathrm{~W}_{7}$ (BRRI dhan $28 \times$ stale seedbed) treatment, while the lowest 1000 -grain weight $\left(19.73 \mathrm{~g}\right.$ ) was obtained from $\mathrm{V}_{2} \mathrm{~W}_{5}$ (BRRI dhan $29 \times$ application of early post-emergence herbicides followed by one hand weeding at 35 DAT) treatment (Table 6). Grain yield was significantly influenced by different cultivars and weeding regimes. The highest grain yield $\left(6.42 \mathrm{t} \mathrm{ha}^{-1}\right)$ was produced in $\mathrm{V}_{1} \mathrm{~W}_{4}$ (BRRI dhan $28 \times$ application of pre-emergence herbicide followed by one hand weeding at 35 DAT) treatment. This finding partially corroborates the findings of Mou et al. (2017) who reported that application of early post-emergence herbicide followed by one hand weeding at 35 DAT produced the highest grain yield. The integrated approach like application of herbicide followed by hand weeding performed better than herbicide or hand weeding alone, such as application of pre-emergence herbicide followed by one hand weeding at 35 DAT. The lowest grain yield (1.86 $\mathrm{t} \mathrm{ha}^{-1}$ ) was produced in $\mathrm{V}_{1} \mathrm{~W}_{0}$ (BRRI dhan $28 \times$ no weeding) condition (Table 6). The lowest grain yield ha ${ }^{-1}$ in the no weeding treatment might be due to the poor performance of yield contributing characters like number of tillers hill $^{-1}$ and grains panicle $^{-1}$. Because of severe weed infestation occurred in the no weeding plots due to competition for moisture, nutrients between weed and rice plants. Straw yield was significantly influenced by different cultivars and weeding regimes. The highest straw yield (7.33 $\mathrm{t} \mathrm{ha}^{-1}$ ) was produced in $\mathrm{V}_{1} \mathrm{~W}_{4}$ (BRRI dhan28 $\times$ application of pre-emergence herbicides followed by one hand weeding at 35 DAT) treatment. The lowest straw yield (4.04 tha ${ }^{-1}$ ) was obtained in $\mathrm{V}_{1} \mathrm{~W}_{0}$ (BRRI dhan $28 \times$ no weeding) treatment (Table 6). Harvest index was significantly influenced by different cultivars and weed management practices. The highest harvest index $(46.69 \%)$ was recorded in $\mathrm{V}_{1} \mathrm{~W}_{4}$ (BRRI dhan $28 \times$ application of pre-emergence herbicides followed by one hand weeding at 35 DAT) treatment which was statistically identical to $V_{1} W_{1}$ (BRRI dhan28 $\times$ application of pre-emergence herbicide) and $\mathrm{V}_{1} \mathrm{~W}_{2}$ (BRRI dhan28 $\times$ application of early post-emergence herbicide). The lowest harvest index (31.48 \%) was recorded in $\mathrm{V}_{1} \mathrm{~W}_{0}$ (BRRI dhan $28 \times$ no weeding) which was followed by $\mathrm{V}_{2} \mathrm{~W}_{0}$ (BRRI dhan29 $\times$ no weeding) (31.97\%) treatment (Table 6).

Table 6. Effect of interaction between cultivars and methods of weed management on yield and yield contributing characters of boro rice.

\begin{tabular}{|c|c|c|c|c|c|c|c|c|c|c|}
\hline $\begin{array}{l}\text { Cultivar } \times \text { Weed } \\
\text { management } \\
\text { practices }\end{array}$ & $\begin{array}{l}\text { Plant } \\
\text { height } \\
(\mathrm{cm})\end{array}$ & $\begin{array}{l}\text { Total } \\
\text { tillers } \\
\text { hill }^{-1} \\
\text { (no.) }\end{array}$ & $\begin{array}{l}\text { Effective } \\
\text { tillers hill } \\
\text { (no.) }\end{array}$ & $\begin{array}{l}\text { Length of } \\
\text { panicle } \\
\text { (cm) }\end{array}$ & $\begin{array}{l}\text { Grain } \\
\text { panicle } \\
\text { (no.) }\end{array}$ & $\begin{array}{l}\text { Sterile } \\
\text { spikelets } \\
\text { panicle } e^{-1} \\
\text { (no.) }\end{array}$ & $\begin{array}{l}\text { 1000- grain } \\
\text { weight (g) }\end{array}$ & $\begin{array}{l}\text { Grain } \\
\text { yield } \\
\left(\text { t ha }^{-1}\right)\end{array}$ & $\begin{array}{l}\text { Straw } \\
\text { yield } \\
\left(\mathrm{t} \mathrm{ha}^{-1}\right)\end{array}$ & $\begin{array}{l}\text { Harvest } \\
\text { index } \\
(\%)\end{array}$ \\
\hline $\mathrm{V}_{1} \mathrm{~W}_{0}$ & 80.80abc* & 8.333 & 6.67 & 21.00 & $108.6 f$ & 21.67 & 20.21 & $1.86 \mathrm{k}$ & $4.04 \mathrm{k}$ & $31.48 f$ \\
\hline$V_{1} W_{1}$ & 80.17abc & 13.67 & 11.33 & 20.33 & $141.6 b c$ & 21.00 & 21.20 & $5.88 \mathrm{bcd}$ & 6.89de & $46.06 a$ \\
\hline $\mathrm{V}_{1} \mathrm{~W}_{2}$ & 79.13a-d & 14.33 & 12.33 & 21.03 & $140.6 b c$ & 18.00 & 19.80 & $6.07 b$ & $6.96 \mathrm{~cd}$ & $46.58 a$ \\
\hline$v_{1} W_{3}$ & 83.00ab & 14.67 & 13.00 & 21.30 & $144.2 b$ & 16.00 & 22.33 & $5.98 b c$ & 7.18ab & $45.43 a b c$ \\
\hline$V_{1} W_{4}$ & $83.60 a$ & 14.67 & 13.33 & 21.37 & $157.5 a$ & 17.33 & 21.80 & $6.42 a$ & $7.33 a$ & $46.69 a$ \\
\hline$V_{1} W_{5}$ & $80.63 a b c$ & 14.33 & 12.67 & 21.47 & $141.6 \mathrm{bc}$ & 17.67 & 21.13 & $5.67 \mathrm{de}$ & $6.82 \mathrm{de}$ & 45.37abc \\
\hline$v_{1} W_{6}$ & $75.60 d$ & 10.67 & & & & & & $4.26 \mathrm{~h}$ & $5.66 \mathrm{~h}$ & 42.94de \\
\hline$V_{1} W_{7}$ & $78.13 \mathrm{~cd}$ & 12.67 & 11.40 & 20.80 & $141.9 b c$ & 15.33 & 23.20 & $5.23 \mathrm{~g}$ & $6.56 \mathrm{~g}$ & $44.36 \mathrm{bcd}$ \\
\hline$v_{2} W_{0}$ & $78.57 \mathrm{bcd}$ & 9.000 & 7.000 & 20.83 & $106.3 f$ & 18.00 & 21.20 & $2.12 \mathrm{j}$ & $4.51 \mathrm{j}$ & $31.97 f$ \\
\hline $\mathrm{V}_{2} \mathrm{~W}_{1}$ & $80.30 a b c$ & 12.00 & 10.17 & 20.97 & $124.4 \mathrm{e}$ & 17.67 & 21.27 & $5.30 \mathrm{~g}$ & 6.74ef & $44.02 \mathrm{~cd}$ \\
\hline $\mathrm{V}_{2} \mathrm{~W}_{2}$ & $78.33 \mathrm{bcd}$ & 11.67 & 10.00 & 21.47 & $133.3 \mathrm{~cd}$ & 20.00 & 20.47 & $5.32 \mathrm{fg}$ & $6.78 \mathrm{e}$ & $43.96 \mathrm{~cd}$ \\
\hline $\mathrm{V}_{2} \mathrm{~W}_{3}$ & $80.93 a b c$ & 13.00 & 11.63 & 21.07 & $133.7 \mathrm{~cd}$ & 15.67 & 21.87 & $5.76 \mathrm{~cd}$ & 7.23ab & $44.34 \mathrm{bcd}$ \\
\hline $\mathrm{V}_{2} \mathrm{~W}_{4}$ & $79.43 a-d$ & 12.67 & 11.20 & 20.63 & $137.9 \mathrm{bc}$ & 18.67 & 22.53 & $5.96 b c$ & $7.10 b c$ & $45.63 a b$ \\
\hline $\mathrm{V}_{2} \mathrm{~W}_{5}$ & 81.67abc & 13.33 & 11.50 & 21.13 & $139.1 b c$ & 18.67 & 19.73 & $5.53 \mathrm{ef}$ & $6.89 \mathrm{de}$ & $44.52 b c$ \\
\hline$v_{2} W_{6}$ & $82.23 a b c$ & 12.33 & 10.33 & 20.93 & $111.7 f$ & 17.00 & 20.47 & $3.72 i$ & $5.18 \mathrm{i}$ & $41.80 \mathrm{e}$ \\
\hline$v_{2} W_{7}$ & 81.17abc & 12.33 & 10.33 & 20.97 & $127.6 \mathrm{de}$ & 17.67 & 21.73 & $5.29 \mathrm{~g}$ & $6.60 \mathrm{fg}$ & $44.49 b c$ \\
\hline Level of sig. & 0.05 & NS & NS & NS & 0.01 & NS & NS & 0.01 & 0.01 & 0.05 \\
\hline CV (\%) & 2.95 & 10.49 & 12.68 & 1.82 & 3.48 & 13.79 & 6.79 & 2.51 & 1.37 & 1.85 \\
\hline
\end{tabular}

*In a column, figures with the same letter (s) or without letter do not differ significantly whereas figures with dissimilar letter differ significantly (as per DMRT), NS = not significant; NS = Not Significant, $\mathrm{V}_{1}=\mathrm{BRRI}$ dhan $28 \mathrm{~V}_{2}=\mathrm{BRRI}$ dhan $29 ; \mathrm{W}_{0}=$ No weeding, $\mathrm{W}_{1}=$ Application of pre-emergence herbicide, $W_{2}=$ Application of early post-emergence herbicide, $W_{3}=$ Application of pre-emergence herbicide followed by application of early post-emergence herbicide, $W_{4}=$ Application of pre-emergence herbicide followed by one hand weeding at 35 DAT, $W_{5}=A p p l i c a t i o n$ of early post-emergence herbicide followed by one hand weeding at $35 \mathrm{DAT}, \mathrm{W}_{6}=$ Stale seedbed, $\mathrm{W}_{7}=$ Stale seedbed followed by application of early post-emergence herbicide. 


\section{Conclusion}

Although cultivar did not exert any significant effect on weed density and dry weight but integrated weed management practices had significant effect on weed density and dry weight. BRRI dhan28 produced higher grain and straw yields than BRRI dhan29. The highest grain yield was obtained from the application of pre-emergence herbicide followed by one hand weeding at 35 DAT. BRRI dhan $28 \times$ application of pre-emergence herbicide followed by one hand weeding at 35 DAT produced the highest grain yield. Application of pre-emergence herbicide followed by one hand weeding at 35 DAT was effective for controlling weed and obtaining highest grain yield. So, for the control of weeds in effective manner and in order to get maximum grain yield in boro rice, BRRI dhan 28 with the application of pre-emergence herbicide followed by one hand weeding at 35 DAT might be recommended.

\section{ACKNOWLEDGEMENTS}

The financial assistance of Ministry of Science and Technology through National Science and Technology (NST) Fellowship (258/NST/2016) for conducting the research is thankfully acknowledged.

Open Access: This is an open access article published under the terms and conditions of Creative Commons AttributionNonCommercial 4.0 International License which permits noncommercial use, distribution, and reproduction in any medium, provided the original author(s) if the sources are credited.

\section{REFERENCES}

Anwar, M.P., Juraimi, A.S., Man, A., Puteh, A., Selamat, A. and Begum, M. (2010). Weed suppressive ability of rice (Oryza sativa L.) germplasm under aerobic soil conditions. Australion Journal of Crop Science, 4: 706-717.

Anwar, M.P., Juraimi, A.S., Puteh, A., Selamat, A., Man, A. and Hakim, M.A (2011). Seeding method and rate influence on weed suppression in aerobic rice. African Journal of Biotechnology, 10: 15259-15271, https://doi.org/10.5897/AJB11.060

Anwar, M.P., Juraimi, A.S., Puteh, A., Man, A. and Rahman, M.M. (2012a). Efficacy, phytotoxicity and economics of different herbicides in aerobic rice. Acta Agriculturae Scandinavica, 62: 604-615, https://doi.org/10.1080/09064710.2012.681060

Anwar, M.P., Juraimi, A.S., Puteh, A., Selamat, A., Rahman, M.M. and Samedani, B. (2012b). Seed priming influences weed competitiveness and productivity of aerobic rice. Acta Agriculturae Scandinavica, 62: 499-509, https://doi.org/10.1080/09064710.2012.662244

Azmi, M. and Baki, B.B. (2002). Impact of continuous direct seeding rice culture on weed species diversity in the Malaysian rice ecosystem. In: Proc. Regional Symposium on Environment and Natural Resources, 10-11 April. Hotel
Renaissance, Kuala Lumpur, Malaysia, pp. 61-67.

BBS. (2018). Statistical Year Book of Bangladesh Bureau of Statistics. Statistics Division, Ministry of Planning, Government of People's Republic of Bangladesh, Dhaka, pp. 125, 140, 144.

BRRI. (2008). Annual Report for 2007. Bangladesh Rice Research Institute Joydevpur, Bangladesh, pp. 28-35.

BRRI. (2018). Modern Rice Cultivation. 21 ${ }^{\text {st }}$ Edition. Bangladesh Rice Research Institute, Goydebpur, Gazipur. pp. 33.

Chauhan, B.S. and Johnson, D.E. (2011). Growth response of direct seeded rice to oxadiazon and bispyribac-sodium in aerobic and saturated soils. Journal of Weed Science, 59: 119-122, https://doi.org/10.1614/WS-D-10-00075.1

FAO. (2004). Production Yearbook for 2004. Food and Agriculture Organization, UN. Rome, Italy, pp. 118.

Gomez, K.A. and Gomez, A.A. (1984). Statistical procedure for Agriculture research. 2nd Edition. John Willey and Sons, New York. pp. 680.

Hussain, S., Ramzan, M., Akhter, M. and Aslam, M. (2008). Weed management in direct seeded rice. Journal of Animal and Plant Science. 18: 86-88, http://www.parc.gov.pk/NARC/narc.html

Islam, S., Salam, M.A., Begum, M., Hossen, K. and Islam, M.S. (2017). Effect of integrated weed management on the performance of short duration transplanted aman rice varieties. European Academic Research, 5(9): 5070-5089.

Juraimi, A.S., Uddin, M.K., Anwar, M.P., Mohamed, M.T.M., Ismail, M.R. and Man, A. (2013). Sustainable weed management in direct seeded rice culture: A review. Australian Journal of Crop Science, 7: 989-1002.

Mamun, A.A. (1990). Weeds and their control: A review of weed research in Bangladesh. Agricultural and Rural Development in Bangladesh. Japan International Co-operation Agency, Dhaka, Bangladesh. The Journal of School Administration Research and Development, 19: 45-72.

Mahajan, G., Chauhan, B.S. and Johnson, D.E. (2009). Weed management in aerobic rice in north-western Indo-Gangetic plains. Journal of Crop Improvement, 23: 366-382, https://doi.org/10.1080/15427520902970458

Mahajan, G. and Chauhan, B.S. (2011). Effects of planting pattern and cultivar on weed and crop growth in aerobic rice system. Weed Technology, 25: 521-525.

Mou, M.R.J., Salam, M.A., Hossen, K., Kato-Noguchi, H. and Islam, M.S. (2017). Effect of weeding regime on the performance of transplanted aman rice. Journal of Agroforestry and Environment, 11(1\&2): 261-266.

Parvez, M.S., Salam, M.A., Kato-Noguchi, H. and Begum, M. (2013). Effect of cultivar and weeding regime on the performance of transplant aman rice. International Journal of Agriculture and Crop Science, 6(11): 654-666, Retrieved from www.ijagcs.com

Phuong, L.T., Denich, M., Vlek, P.L.G. and Balasubramanian, V. (2005). Suppressing weeds in direct seeded lowland rice: Effects of methods and rates of seeding. Journal of Agronomy and Crop Science, 191: 185-94, https://doi.org/10.1111/j.1439-037X.2005.00151.x

Prasad, R. (2011). Aerobic rice systems. Advances in Agronomy, 111: 207-233, https://doi.org/10.1016/B978-0-12-387689-8.00003-5

Rao, A.N., Johnson, I.J., Sivaprasad, B., Ladha, J.K. and Mortimer, A.M. (2007). Weed management in direct seeded rice. Advances in Agronomy, 93: 153-255.

Rahman, M.M., Sahid, I.B. and Juraimi, A.S. (2010). Study of resistant biotypes of Echinochloa crusgalli in Malaysia. Australian Journal Crop Science, 4: 107-115.

Sarker, P.A. (1979) Study on varietal response to planting geometry and in transplanted rice. Allahabad Farmer, 50(4): 357-358.

Sunil, C.M., Shekara, B.G., Kalyanmurthy, K.N. and Shankaralingapa, B.C. (2010) Growth and yield of aerobic rice as influenced by integrated weed management practices. Indian Journal of Weed Science, 42: 180-183.

Zhao, D.L., Atlin, G.N., Bastiaans, L. and Spiertz, J.H.J. (2006). Comparing rice germplasm groups for growth, grain yield and weed suppressive ability under aerobic soil conditions. Journal of Weed Research, 46: 444-452, https://doi.org/10.1111/j.1365-3180.2006.00529.x 